\title{
Genotypic Variation for Phosphorus Efficiency of Pigeonpea Genotypes under Varied Phosphorus Levels
}

\author{
Sukhpreet Kaur Sidhu $^{1 *}$, Jagmeet Kaur ${ }^{2}$ and Satvir Kaur Grewal ${ }^{3}$ \\ ${ }^{1}$ Department of Botany, Punjab Agricultural University, Ludhiana 141004, Punjab, India \\ ${ }^{2}$ Department of Plant Breeding and Genetics, Punjab Agricultural University, \\ Ludhiana 141004, Punjab, India \\ ${ }^{3}$ Department of Biochemistry, Punjab Agricultural University, Ludhiana 141004, Punjab, India \\ *Corresponding author
}

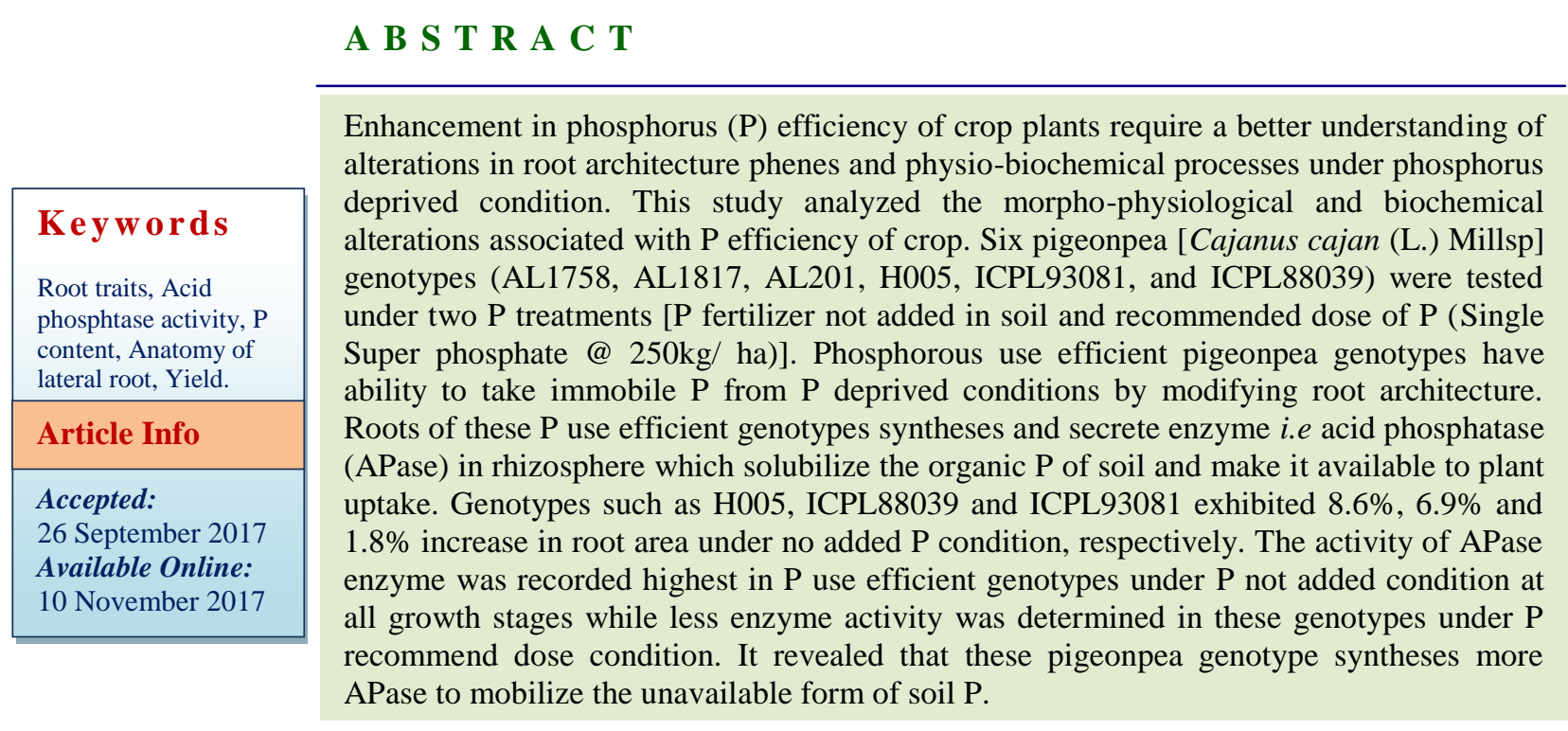

\section{Introduction}

Phosphorus $(\mathrm{P})$ plays vital role in every phase of plant growth and development. It is a fundamental structural constituent of coenzymes, phosphoproteins, phospholipids and sugar phosphates (Veneklaas et al., 2012). Phosphorus uptake by the roots from the soil solution is as phosphate ions $\left(\mathrm{HPO}_{4}{ }^{-2}\right.$ and $\mathrm{H}_{2} \mathrm{PO}_{4}{ }^{-}$) moreover, some soluble organic phosphorus compounds are also absorbed (Rubya and Md, 2016). Phosphorus never found as a free state in soil, it forms complexes with several cations such as Fe, $\mathrm{Ca}, \mathrm{Mg}$ and $\mathrm{Al}$. Phosphorus is a nonrenewable because the phosphate rich rocks are formed slowly (Clemens et al., 2016). It has been hypothesized that rock phosphate will exhaust in 2033-34 years and then production of fertilizers reduced and the prices are expected to rise (Cordell et al., 2009). Phosphorus fertilizers due to hike in prices as well as environmental contaminants need to be replaced with safe and economical 
alternatives, $\mathrm{P}$ use efficient genotypes can help to reduce the use of fertilizer.

Pigeonpea is one of the chief protein rich legume crop belongs to Fabaceae family. The shoots of pigeonpea are used as fuel and seeds can be eaten as dahl. The leaves and seed pods are used to feed livestock. Ability of crop to resist drought and fix nitrogen in soil makes it good choice for rainfed and irrigated areas. Pigeonpea occupied total area of 3.9 million hectare with production of 3.2 million tonnes during 2013-2014 in India (INDIASTAT, 2015). Some of the pigeonpea genotypes have ability to uptake more $\mathrm{P}$ with enhanced activity of root acid phosphatase and by developing some specific physiological mechanisms under $\mathrm{P}$ deficient conditions (Krishnappa and Hussain, 2014).

Phosphorus acquisition from the soil depends on root architecture phenes. Root architecture is highly flexible trait adapted according to soil environment and varies among crop species. Its flexibility is controlled by growth substances, expression of $\mathrm{P}$ transporters and heritable genes. Modifications in root morphology under $\mathrm{P}$ deficient soil condition are associated with phytohormone concentration. Several studies have implicated that localized phytohormone concentration, transmission of hormonal signals and sugar demonstrate considerable role in root growth during $\mathrm{P}$ deficiency (Karthikeyan et al., 2007). Plants have developed various adaptive strategies for better acquisition and utilization of $\mathrm{P}$ (Lambers et al., 2006). Phosphorus accumulation increased due to higher $\mathrm{P}$ uptake efficiency, which can be linked to superior root character like high root area, root biomass, root length, root volume and altered plant metabolism like organic acid exudation and root acid phosphatase activity in $\mathrm{P}$ use efficient genotypes play a crucial role in supporting plants to more acquisition of $\mathrm{P}$ under P deficient soil conditions (Krishnappa et al., 2011). Some genes of plants activated in low P fertility soil but the function of these genes were lost when plants grown in high input -P conditions (Wissuwa et al., 2009).

In soil supplied with fertilizers, $\mathrm{P}$ availability higher in top layers of soil. Crop plants with better root traits (more root surface area, hairs, branching and volume) are more capable to acquire $\mathrm{P}$ from top soil (Manschadi et al., 2013). Root characters i.e., root length, fineness, surface area and root hair density affected by the behavior of plant in $\mathrm{P}$ deficient soils (Rao et al., 1996).

Superior root architecture is an inducible trait (Marschner, 1998) and significance for $P$ acquisition as diffusion to the root surface is the rate-limiting step, especially under P-fixed soil of tropics in which soil nutrient supply could be patchy (Hodge, 2004). If the majority of applied $\mathrm{P}$ to soil can be transformed into fixed forms of $\mathrm{P}$ that cannot be easily acquired by plants then development of $\mathrm{P}$ efficient genotypes with immense potential to grow in low $\mathrm{P}$ soil is, therefore a main objective of plant breeding (Yan et al., 2004). The activity of $P$ solubilizing enzymes in the processes of dissolution of organic phosphates i.e acid and alkaline phosphatases have been also investigated from some species, the effects of these enzymes are evident (Rengel and Marschner, 2005). The methods of adaption to $\mathrm{P}$ stress in pigeonpea are ambiguous so, it is necessary to screen pigeonpea genotypes for $\mathrm{P}$ efficiency from large pool of germplasm. Wide variations occurs in pulse crops for nutrient requirement; thereby, these crops possess differential capability to utilize plant nutrient from different soil layers, resulting in better use efficiency of the applied fertilizers and residual fertility (Singh et al., 2005). The ability of plants to access $\mathrm{P}$ under deficient condition depends not only on intrinsic genetic makeup of plant, but also on 
important adaptive traits such as alternation in root characteristics, exudation of organic acids, change in the rhizosphere $\mathrm{pH}$ and increased capacity of roots to explore various layers of soil (Schachtman et al., 1998).

Plants have developed other strategies for $\mathrm{P}$ uptake and utilization in $\mathrm{P}$ limiting environment that include: remobilization of internal inorganic phosphate, symbioses (mycorrhizal), more synthesis and release of root enzyme phosphatases, exudation of organic acids, and modification of root architecture (Plaxton, 2004). Acid phosphatase mobilizes organically bound $\mathrm{P}$ by catalysing hydrolytic cleavage of the $\mathrm{C}-\mathrm{O}-\mathrm{P}$ ester bond in soil and release inorganic $\mathrm{P}$ to plants. Cellular reallocation of $\mathrm{P}$ by acid phosphatases in crops was also investigated (Wang et al., 2010). Plants have ability to alter various mechanisms to ameliorate their $\mathrm{P}$ acquisition (root architecture, angles, symbiosis and exudates) and allocation of $\mathrm{P}$ within plant (Clemens et al., 2016). Acquisition of applied $\mathrm{P}$ from soil by plants depends on root architecture. Plants have developed new properties for efficient use of available soil $\mathrm{P}$ and to mobilize $\mathrm{P}$ from less available soil $\mathrm{P}$ fractions. The adaptive properties developed by plants in response to $P$ availability are the alteration of their root morphology. Therefore, the present investigation was undertaken to examine the morpho-physiological and biochemical alterations in different parts of pigeonpea genotypes at growth various stages.

\section{Materials and Methods}

\section{Location of experiment and field layout}

The experiment was conducted in the experimental area of the Pulse section, Department of Plant Breeding and Genetics, Punjab Agricultural University, Ludhiana during Kharif 2016. Ludhiana represents the
Indo-Gangetic alluvial plains, situated at $30^{\circ}$ $54 ' \mathrm{~N}$ latitude, $75^{\circ}-48$ 'E longitude and at an altitude of $247 \mathrm{~m}$ above mean sea level. Ludhiana is positioned in South-Central plain region of Punjab having subtropical and semiarid climate. Pre planting soil analysis was carried out and samples of the soil were collected randomly at depth of $0-15 \mathrm{~cm}$ from the experimental area were randomly selected from five places at the start of the experiment to determine the physicochemical properties of the soil. The soil of the experimental area was loamy sand with organic C $(0.241 \%), \mathrm{pH}$ of $\sim 7.4$, available $\mathrm{P}(9.8 \mathrm{~kg} / \mathrm{acre})$ and potassium (75 kg/ acre). Six pigeonpea genotypes namely AL1758, AL1817, AL201, H005, ICPL93081, ICPL88039 were sown with two treatments [P fertilizer not added in soil and recommended dose of $\mathrm{P}$ (40 kg/ha)] and three replications in the field. Seeds of these genotypes were procured from International Crops Research Institute for the Semi-Arid Tropics (ICRISAT) and Agricultural University of Punjab (PAU). The plot consisted of four rows, each of four meter length with a row to row distance $50 \mathrm{~cm}$ and plant to plant $25 \mathrm{~cm}$. Experimental design was randomized block design and the crop was sown as recommended by Package of Practices for Kharif crops, PAU, Ludhiana (2015). Morpho-physiological and biochemical parameters were recorded at vegetative, flower initiation and pod filling stages.

\section{Morpho- physiological parameters}

Root area was measured with the help of "Delta-T HP root scanner". Root was scanned by scanner and evaluated in the DOS based software (Delta-T Devices Ltd). Leaf area of all the leaves was recorded using "Leaf Area Meter CID Inc -213" and expressed as $\mathrm{cm}^{2}$.

Specific leaf weight (SLW): After taking the leaf area these leaves were subsequently dried 
for $48 \mathrm{hrs}$ at $60^{\circ} \mathrm{C}$ and used for specific leaf weight (mg cm plant $\left.^{-1}\right)$ determined by following formula:

Leaf dry weight (mg) Specific Leaf weight $($ SLW $)=$

Leaf Area $(\mathrm{cm} 2)$

Above ground plant biomass were recorded after drying the plants in an oven at $70 \pm 1^{\circ} \mathrm{C}$ for $48 \mathrm{hr}$ and plant biomass was expressed in $\mathrm{g}$ plant $^{-1}$. Root shoot ratio calculated as the ratio between root dry weight and shoot dry weight. Photosynthetic rate and internal $\mathrm{CO}_{2}$ concentration were measured by using portable infra-red gas analyser (LI-6400XT, LICOR). Rate of photosynthesis is expressed as $\mu \mathrm{mol} \mathrm{CO}^{2} \mathrm{~m}^{-2} \mathrm{~s}^{-1}$. A LED light source attached to leaf chamber and $1500 \mu \mathrm{mol} \mathrm{m}^{-2}$ $\mathrm{s}^{-1}$ a saturating photosynthetically active radiation (PAR) was supplied. The photosynthetic rate was measured of third trifoliate leaf from top.

\section{Biochemical analysis}

Fresh root samples were used for the estimation of acid phosphatase enzyme (APase) activity (Kouas et al., 2009). Root tissue $0.1 \mathrm{~g}$ was homogenized in a chilled glass mortar with a pestle. The extraction buffer containing $0.1 \mathrm{M}$ acetate buffer (7.4), $6 \mathrm{mM} \quad \beta$-mercaptoethanol, $6 \mathrm{~g}$ polyvinylpolypyrolidone and $0.1 \mathrm{mM}$ phenyl methyl sulfonyl fluoride was used. The homogenate was centrifuged at $30000 \mathrm{rpm}$ for 30 minutes at $4^{\circ} \mathrm{C}$. Supernatant was used for estimating the activity of acid phosphatase. The reaction mixture contained $100 \mathrm{mM}$ sodium acetate buffer $\quad(\mathrm{pH} \quad 5.8), \quad 5 \mathrm{mM} \quad p$ nitrophenylphosphate and $50 \mu \mathrm{l}$ of enzyme extract was incubated at $37^{\circ} \mathrm{C}$ for 20 minutes. The solution was then made alkaline with 1 $\mathrm{ml} 0.5 \mathrm{M} \mathrm{NaOH}$ to stop the reaction and optical density of yellow colored product i.e $p$-nitrophenol was recorded at $405 \mathrm{~nm}$. A standard curve was also prepared simultaneously using graded concentration of $p$ - nitrophenol. Enzyme activity was expressed as $\mu$ moles of $p$ - nitophenol $\mathrm{min}^{-1} \mathrm{~g}^{-}$ 1. The P content in root, stem and leaf was estimated by vanado-molybdate method (Jackson, 1973).

Native polyacrylamide gel electrophorsis for acid phosphatase

Proteins from root tissues of pigeonpea cultivars were extracted in $1 \mathrm{ml}$ of $25 \mathrm{mM}$ sodium phosphate buffer ( $\mathrm{pH} 7.5)$ containing $1 \%$ PVP, the tissue was ground in pestle and mortar. The homogenized tissue was centrifuged in a cooling centrifuge at $4 \pm 1{ }^{\circ} \mathrm{C}$ for $20 \mathrm{~min}$ at $10,000 \mathrm{rpm}$. Supernatant was collected as crude protein sample and stored at $4 \pm 1{ }^{\circ} \mathrm{C} .40 \mu \mathrm{g}$ proteins from root, per lane, were loaded into native polyacrylamide gel $(7.5 \%$ w/v stacking gel and $10 \%$ w/v resolving gel). Electrophoresis was carried out at constant voltage of $50 \mathrm{~V}$ until the samples travel through stacking gel after that voltage was increased to $70 \mathrm{~V}$. The native gels were run at low temperature $\left(4 \pm 1{ }^{0} \mathrm{C}\right)$. After completion of the electrophoresis, gels were washed three times in $0.1 \mathrm{mM}$ sodium acetate buffer ( $\mathrm{pH}$ 5.0) and acid phosphatase activity was stained with $0.2 \%$ diazo dye and $0.2 \%$ p-nitrophenyl phosphate. Dark brown coloured bands of acid phosphatase (APases) were appeared after 40 minutes (Ciereszko et al., 2011) with little modification for staining.

\section{Lateral root anatomy}

Roots of two genotypes were chosen for anatomical studies. Selected roots were preserved in FAA (formaldehyde: acetic acid: alcohol) solution which was prepared according to Sass (1958). The stored root material was dehydrated using ethyl alcohol series which consisted of 10, 30, 50, 70, 90, 95\% alcohol and two changes in absolute 
alcohol. The embedding of lateral root material was undertaken in paraffin wax and small wax blocks of the embedded material were mounted on a wooden block for microtomy. Serial sections of the roots were cut on a rotary microtome at $10 \mu \mathrm{m}$ thickness. Before staining, the slides were dewaxed by using xylene. Root sections were hydrated using downward series of xylene: alcohol (3:1, 1:1, 1:3) and alcohol (absolute, 95, 70, 50, 30 and 10\%) series. Then slides were stained with erythrosine. Image analysis was performed with ImageJ $1.51 \mathrm{~J} 8$ software.

\section{Yield and yield attributes}

Yield was recorded at harvest from randomly selected five plants from each replicated plot. All the plants from each plot were sun dried for 2-3 days. Grain yield was recorded on the basis of plot and then converted into $\mathrm{kg} \mathrm{ha}^{-1}$.

\section{Statistical analysis}

The data were subject to analysis of variance (ANOVA) in a randomized complete block design as per the standard procedures. Critical difference values at $5 \%$ level of significance were calculated to compare mean values by CPCS-1 software.

\section{Results and Discussion}

Plant height increased gradually with crop developmental stages. At vegetative stage tallest plants were observed in AL201 while shortest in AL1758 under no P added condition (-P) and AL201 attained maximum plant height followed by AL1817 at pod filing stage (Table 1). The decrease of plant height of genotypes grown under no $\mathrm{P}$ added was accompanied by a decrease in plant biomass. At pod filing stage ICPL88039 accumulated significantly more biomass followed by H005 and AL201 under recommended dose of $\mathrm{P}$ condition $(+\mathrm{P})$. No significant differences were observed between biomass of genotypes at flower initiation under both $-\mathrm{P}$ and $+\mathrm{P}$ conditions (Table 2). Among six genotypes ICPL 88039 maximum number of branches and number of leaves at all stages under both $\mathrm{P}$ treatments (Table 2). Leaf area of AL1817, ICPL93081, AL201, AL1758 was reduced by $4.4 \%, 4.6 \%$ $5.5 \%, 5.3 \%$ while reduction of leaf area was less in $\mathrm{H} 005$ (3.6\%) in response to no added P. ICPL880369 showed $3.3 \%$ an increase in leaf area at vegetative stage (Fig. 1). The number of leaves and leaf area decreased due to the low P supply conditions (De Groot et al., 2001). No $\mathrm{P}$ added condition triggers increase in root area of $\mathrm{P}$ use efficient genotypes. In the present study, genotypes such as H005, ICPL88039 and ICPL93081 exhibited $8.6 \%, 6.9 \%$ and $1.8 \%$ increase in root area under no added $\mathrm{P}$ condition, respectively at vegetative stage. Maximum root area was recorded in ICPL88039 (1749.43 $\mathrm{mm}^{2}$ ) followed by H005 $\left(1636.70 \mathrm{~mm}^{2}\right)$ under no added $\mathrm{P}$ condition (Fig. 2). An increase in root area in response to $\mathrm{P}$ stress might enhance $\mathrm{P}$ acquisition from the soil. Phosphorus efficient genotypes have usually highly branched root systems with numerous basal roots, while the inefficient plants had smaller, less branched roots (Hammond et al., 2009). Root hair density and increase in lateral branching are the most useful root traits for phosphorus use efficiency (Clemens et al., 2016). Plants can also turn on a set of adaptive responses to boost $\mathrm{P}$ uptake and $\mathrm{P}$ recycling by reprogramming of physiology processes and alter root structure (Jain et al., 2007) to maintain their development rate as feasible (Gutschick and Kay 1995). At flowering stage ICPL88039 had maximum (0.193 and 0.231) root- shoot ratio (RSR) under both $\mathrm{P}$ treatments, respectively while AL201 had minimum RSR (Fig. 3). High root- shoot ratio demonstrated that growth of root was more than shoot to cope with $\mathrm{P}$ stress. Increase in root-shoot ratio is regarded as vital change for adaptation to $\mathrm{P}$ deficiency 
in plants (Vandamme et al., 2016, Hammond and White, 2011).

\section{Photosynthetic rate and internal $\mathrm{CO}_{2}$ concentration}

Our results of photosynthetic efficiency demonstrated that genotypes grown under no added $\mathrm{P}$ showed $1.2 \%$ and $2.2 \%$ increase at vegetative and flower initiation phase. It revealed that $\mathrm{P}$ efficient genotypes maintained photosynthesis under $\mathrm{P}$ limited conditions. Net photosynthesis efficiency increased from vegetative to flowering stage and then declined towards maturity. Under no added $\mathrm{P}$ condition, maximum photosynthesis rate was recorded in ICPL88039 followed by H005 and ICPL93081 at flowering stage (Table 3). Internal $\mathrm{CO}_{2}$ concentration $(\mathrm{Ci})$ followed a similar trend as the photosynthesis rate. The reduction of $\mathrm{Ci}$ was higher in $\mathrm{P}$ use non efficient genotypes than in $\mathrm{P}$ use efficient (Table 3). Difference between mean values of genotypes for photosynthesis efficiency and $\mathrm{Ci}$ was significant at all stages. The biomass production and yield of crops are largely dependent on photosynthesis. Inhibition of photosynthesis by $\mathrm{P}$ limitation has often been explained by depressing the Calvin cycle activity, in particular, by depressing the amount and activity of Rubisco and the regeneration of Ribulose-1,5-bisphosphate (Lauer et al., 1989). Photosynthesis is the most important photochemical sink for energy absorbed by leaves, and therefore the photosynthetic apparatus is liable to be exposed to harmful excess light energy due the strong $\mathrm{CO}_{2}$ assimilation inhibition in plants evoked by $\mathrm{P}$ deficiency (Richardson et al., 2011; Veronica et al., 2016).

\section{Root acid phosphatase activity}

An acid phosphatase activity was recorded lower in genotypes namely AL1817 and AL1758 under both P treatments than other genotypes at all stages (Fig. 4). At vegetative and flower initiation stage 23.0 and 20.9 fold increase in APase activity was recorded under $-\mathrm{P}$ over $+\mathrm{P}$ condition, respectively. The acid phosphatase activity in root of ICPL93081, H005 and ICPL88039 under no added P was 29.0, 11.3 and 10.8 fold higher than the recommended $\mathrm{P}$ dose condition at vegetative stage. Maximum activity of enzyme in all genotypes was observed under no added $\mathrm{P}$ than $\mathrm{P}$ recommended dose condition. It revealed that low $\mathrm{P}$ condition stimulate the root to syntheses and secrete more APase in soil to mobilize the unavailable form of P. In pigeonpea, root acid phosphatase activity of high $\mathrm{P}$ uptake genotypes was $74.88 \%$ increased under $\mathrm{P}$ deficient condition as compared to $\mathrm{P}$ sufficient condition (Krishnappa and Hussain, 2014). Acid phosphatase activity is not constant in plants; it changes according to soil environment condition. In low $\mathrm{P}$ soil microenvironment, genes related to $\mathrm{P}$ solubilizing enzymes such as acid phosphatase and high affinity $P$ transporters are upregulated for $\mathrm{P}$ uptake (Clemens et al., 2016).

\section{Native polyacrylamide gel electrophorsis for root acid phosphatase}

Isozymic pattern of APase differed with the growth stages viz., vegetative stage, flower initiation and pod filling stage (Fig. $5 \mathrm{a}, \mathrm{b}$ and c). The results showed variation in number and intensity of bands. Bands were more intense under no added $\mathrm{P}$ in almost all the genotypes as compared to $\mathrm{P}$ recommend dose condition. Electrophoretic analysis of protein patterns of acid phosphatase showed that in genotype ICPL88039, two isoforms were detected under no added $\mathrm{P}$ condition. Intensity of bands was more in ICPL88039, H005 and ICPL93081 at vegetative stage under no added $\mathrm{P}$ condition. At flower initiation stage, in no added P condition bands of ICPL88039, H005 and AL201 showed more intensity. 
Table.1 Plant height $(\mathrm{cm})$ of pigeonpea genotypes at various growth stages under $+\mathrm{P}$ and $-\mathrm{P}$ conditions

\begin{tabular}{|l|l|l|l|l|l|c|}
\hline \multirow{2}{*}{ Genotypes } & \multicolumn{2}{|c|}{ Vegetative stage } & \multicolumn{2}{c|}{ Flower initiation } & \multicolumn{2}{l|}{ Pod filling stage } \\
\cline { 2 - 7 } & $+\mathrm{P}$ & $-\mathrm{P}$ & $+\mathrm{P}$ & $-\mathrm{P}$ & $+\mathrm{P}$ & $-\mathrm{P}$ \\
\hline AL1817 & $133.2 \pm 1.30$ & $124.1 \pm 0.77$ & $175.8 \pm 2.38$ & $154.3 \pm 1.00$ & $208.1 \pm 1.92$ & $199.5 \pm 1.58$ \\
\hline AL201 & $132.3 \pm 1.34$ & $129.3 \pm 1.44$ & $161.2 \pm 1.96$ & $154.1 \pm 1.14$ & $204.2 \pm 2.26$ & $201.4 \pm 0.48$ \\
\hline AL1758 & $126.9 \pm 1.72$ & $121.7 \pm 1.01$ & $155.2 \pm 1.84$ & $145.5 \pm 0.93$ & $194.4 \pm 0.88$ & $191.6 \pm 1.93$ \\
\hline H005 & $136.1 \pm 0.70$ & $125.6 \pm 0.55$ & $174.3 \pm 1.95$ & $163.4 \pm 1.29$ & $204.5 \pm 2.10$ & $198.3 \pm 1.59$ \\
\hline ICPL93081 & $128.6 \pm 1.49$ & $122.3 \pm 0.79$ & $165.5 \pm 0.95$ & $151.8 \pm 1.69$ & $198.2 \pm 1.51$ & $191.2 \pm 1.49$ \\
\hline ICPL88039 & $136.1 \pm 0.86$ & $128.0 \pm 0.88$ & $178.2 \pm 1.75$ & $173.5 \pm 2.17$ & $213.4 \pm 2.12$ & $197.1 \pm 1.89$ \\
\hline C.D (5\%) & NS & 5.06 & 10.40 & 8.42 & 10.70 & NS \\
\hline
\end{tabular}

Table. 2 Number of branches and biomass of pigeonpea genotypes at various growth stages under $+\mathrm{P}$ and $-\mathrm{P}$ conditions

\begin{tabular}{|l|l|l|l|l|l|l|l|l|l|l|l|l|l|}
\hline & \multicolumn{9}{|c|}{ Number of branches } & \multicolumn{4}{c|}{ Biomass/plant (g) } \\
\cline { 2 - 15 } & Vegetative & Flower initiation & \multicolumn{1}{|c|}{ Pod filling } & \multicolumn{2}{c|}{ Vegetative } & \multicolumn{2}{|c|}{ Flower initiation } & \multicolumn{2}{l|}{ Pod filling } \\
\cline { 2 - 14 } Genotypes & $+\mathrm{P}$ & $-\mathrm{P}$ & $+\mathrm{P}$ & $-\mathrm{P}$ & $+\mathrm{P}$ & $-\mathrm{P}$ & $+\mathrm{P}$ & $-\mathrm{P}$ & $+\mathrm{P}$ & $-\mathrm{P}$ & $+\mathrm{P}$ & $-\mathrm{P}$ \\
\hline AL1817 & 8 & 8 & 16 & 14 & 17 & 17 & 21.07 & 18.81 & 73.94 & 68.61 & 95.58 & 92.71 \\
\hline AL201 & 8 & 6 & 17 & 15 & 18 & 15 & 20.01 & 17.94 & 67.53 & 62.87 & 96.74 & 92.59 \\
\hline AL1758 & 5 & 5 & 14 & 12 & 22 & 16 & 21.12 & 19.65 & 67.89 & 64.22 & 86.69 & 83.82 \\
\hline H005 & 6 & 6 & 17 & 19 & 21 & 22 & 22.84 & 19.48 & 77.51 & 70.54 & 97.23 & 93.74 \\
\hline ICPL93081 & 7 & 7 & 17 & 19 & 21 & 21 & 20.21 & 17.74 & 72.50 & 69.03 & 89.52 & 87.36 \\
\hline ICPL88039 & 9 & 9 & 19 & 21 & 22 & 23 & 21.92 & 20.03 & 79.74 & 72.17 & 98.05 & 97.32 \\
\hline CD (5\%) & 1.98 & 2.09 & NS & 2.96 & 3.54 & 2.62 & 1.65 & 1.60 & NS & NS & 5.51 & 5.31 \\
\hline
\end{tabular}

Table.3 Photosynthetic rate and internal $\mathrm{CO}$ concentration of pigeonpea genotypes at various growth stages under $+\mathrm{P}$ and $-\mathrm{P}$ conditions

\begin{tabular}{|c|c|c|c|c|c|c|c|c|c|c|c|c|}
\hline \multirow{3}{*}{ Genotypes } & \multicolumn{6}{|c|}{ Photosynthesis rate $\left(\mu \mathrm{mol} \mathrm{CO}{ }_{2} / \mathrm{m}^{2} / \mathrm{s}\right)$} & \multicolumn{6}{|c|}{ Internal $\mathrm{CO}_{2}$ concentration $(\mathrm{ppm})$} \\
\hline & \multicolumn{2}{|c|}{ Vegetative } & \multicolumn{2}{|c|}{ Flower initiation } & \multicolumn{2}{|c|}{ Pod filling } & \multicolumn{2}{|c|}{ Vegetative } & \multicolumn{2}{|c|}{ Flower initiation } & \multicolumn{2}{|c|}{ Pod filling } \\
\hline & $+\mathbf{P}$ & $-\mathbf{P}$ & $+\mathbf{P}$ & $-\mathbf{P}$ & $+\mathbf{P}$ & $-\mathbf{P}$ & $+\mathbf{P}$ & $-\mathbf{P}$ & $+\mathbf{P}$ & $-\mathbf{P}$ & $+\mathbf{P}$ & $-\mathbf{P}$ \\
\hline AL1817 & 2.78 & 2.57 & 9.74 & 8.63 & 4.53 & 4.35 & 165.7 & 157.7 & 198.0 & 192.3 & 178.7 & 171.7 \\
\hline AL201 & 2.85 & 2.78 & 11.50 & 10.12 & 5.43 & 4.83 & 144.3 & 140.0 & 188.0 & 183.0 & 152.3 & 142.3 \\
\hline AL1758 & 2.75 & 2.69 & 8.80 & 7.76 & 5.54 & 5.34 & 143.0 & 139.3 & 184.7 & 181.3 & 176.0 & 173.7 \\
\hline $\mathrm{H} 005$ & 3.55 & 3.75 & 11.25 & 14.47 & 6.33 & 6.20 & 168.0 & 170.3 & 204.3 & 211.3 & 193.7 & 197.3 \\
\hline ICPL93081 & 3.72 & 3.88 & 11.14 & 11.93 & 5.73 & 5.77 & 169.3 & 172.0 & 201.0 & 209.0 & 192.3 & 196.0 \\
\hline ICPL88039 & 3.95 & 4.18 & 14.73 & 15.73 & 7.67 & 7.83 & 183.3 & 190.7 & 212.3 & 223.0 & 201.7 & 207.0 \\
\hline $\mathrm{CD}(5 \%)$ & NS & 0.99 & NS & 4.95 & 1.54 & 1.53 & 12.05 & 11.80 & 12.20 & 13.77 & 10.13 & 7.76 \\
\hline
\end{tabular}

Table.4 Xylem vessel characteristics of two pigeonpea genotypes

\begin{tabular}{|l|c|l|l|l|l|l|l|}
\hline Genotypes & $\begin{array}{l}\text { Number } \\
\text { of small } \\
\text { xylem } \\
\text { vessels }\end{array}$ & $\begin{array}{l}\text { Number of } \\
\text { large } \\
\text { metaxylem } \\
\text { vessels }\end{array}$ & $\begin{array}{l}\text { Range of } \\
\text { vessel } \\
\text { diameter } \\
(\mathrm{mm})\end{array}$ & $\begin{array}{l}\text { Average size } \\
\text { of xylem } \\
\text { vessels }(\mathrm{mm})\end{array}$ & $\begin{array}{l}\text { Standard } \\
\text { deviation }\end{array}$ & $\begin{array}{l}\text { Diameter } \\
\text { of root } \\
\text { section } \\
(\mathrm{mm})\end{array}$ & $\begin{array}{l}\text { Average area } \\
\text { of small and } \\
\text { large xylem } \\
\text { vessels }\end{array}$ \\
\hline ICPL88039 & 50 & 10 & $0.29-0.129$ & 0.060 & 13.312 & 0.742 & $4.80 \mathrm{E}-05$ \\
\hline AL1758 & 25 & 19 & $0.25-0.146$ & 0.067 & 15.815 & 0.482 & $5.36 \mathrm{E}-05$ \\
\hline
\end{tabular}


Int.J.Curr.Microbiol.App.Sci (2017) 6(11): 3633-3647

Fig.1 Leaf area $\left(\mathrm{cm}^{2}\right)$ of pigeonpea genotypes at vegetative stages under $+\mathrm{P}$ and $-\mathrm{P}$ conditions

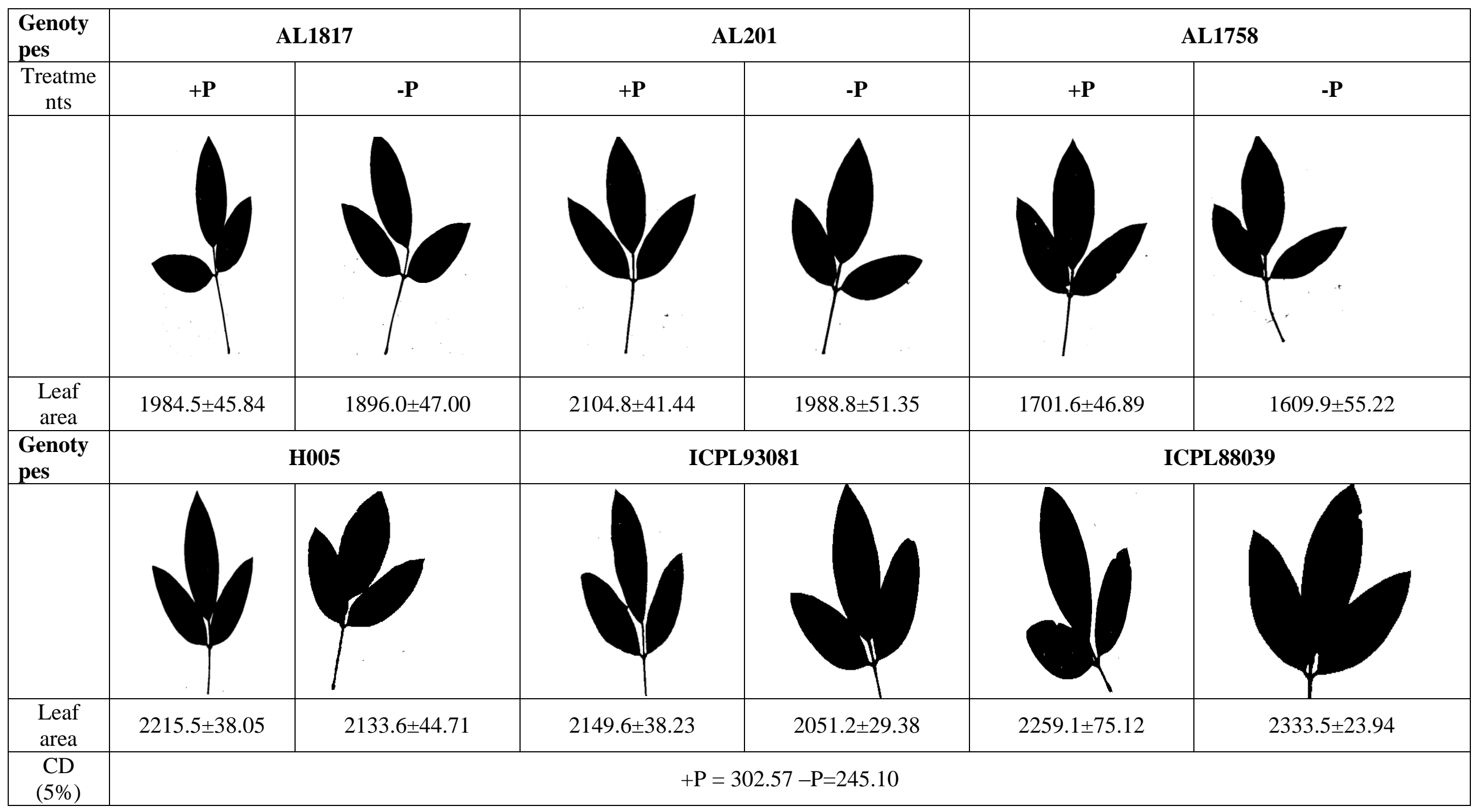


Int.J.Curr.Microbiol.App.Sci (2017) 6(11): 3633-3647

Fig.2 Root area $\left(\mathrm{mm}^{2}\right)$ of pigeonpea genotypes at vegetative stage under $+\mathrm{P}$ and $-\mathrm{P}$ conditions

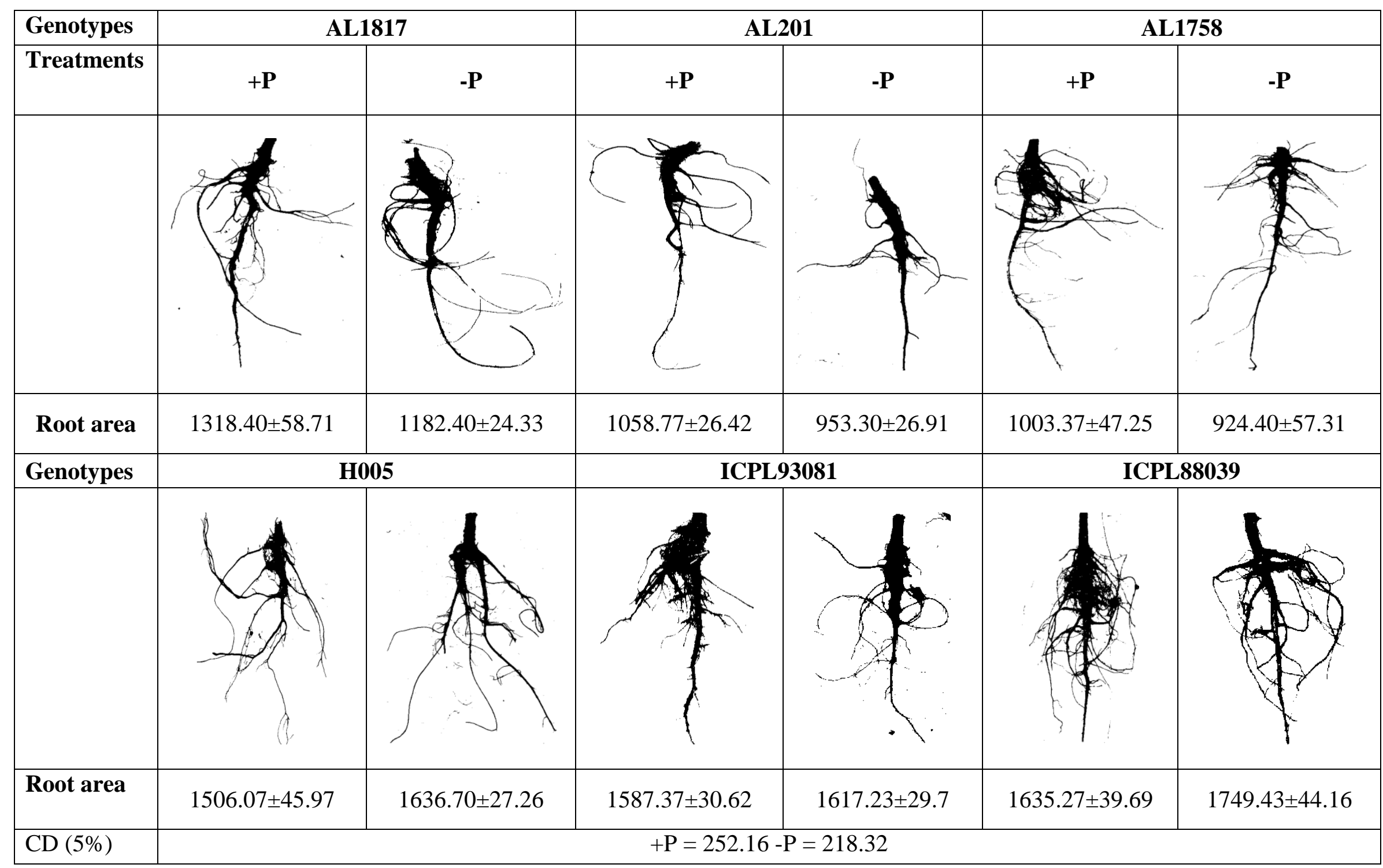


Fig.3 Root-shoot ratio of pigeonpea genotypes at various growth stages under $+\mathrm{P}$ and $-\mathrm{P}$ condition

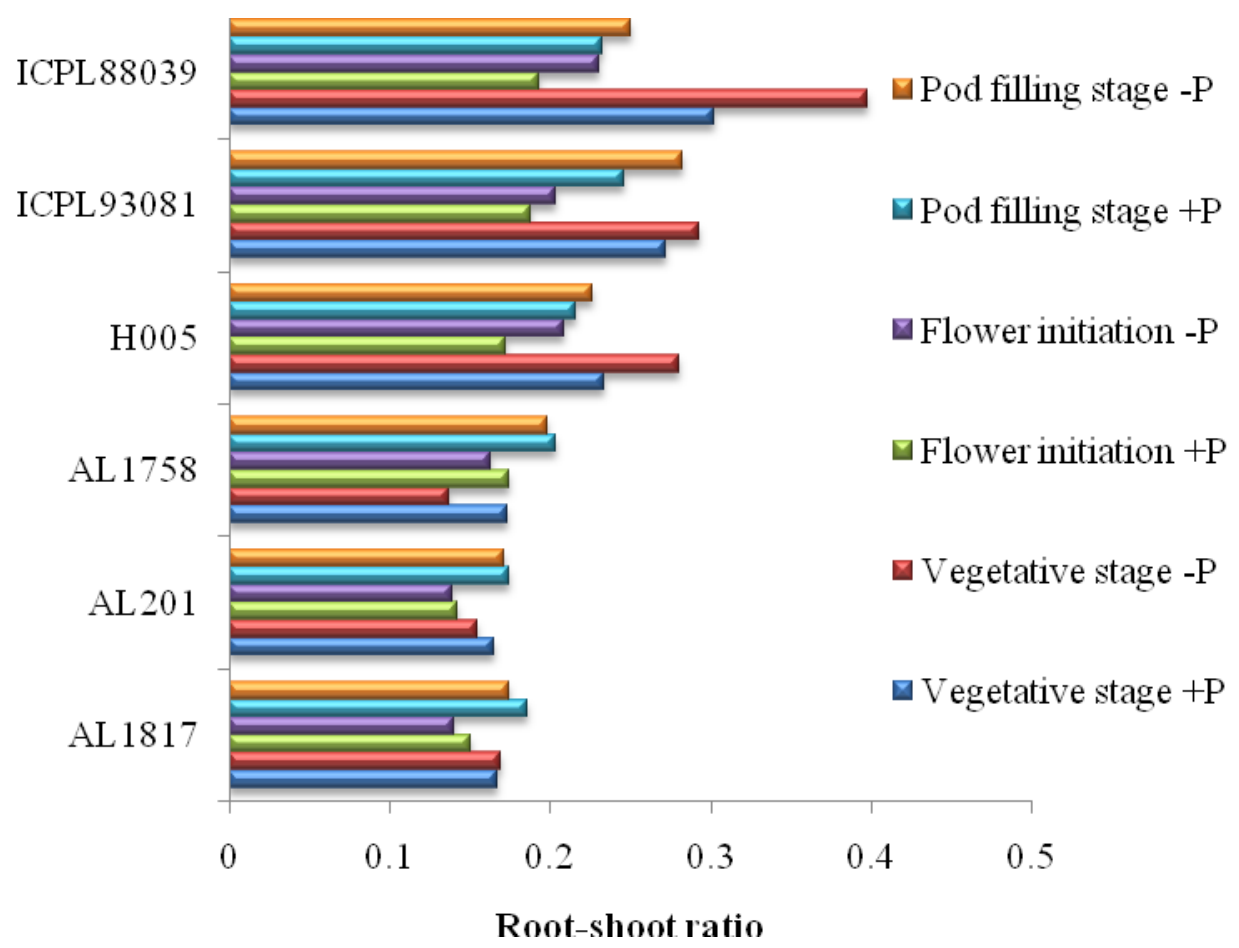

Fig.4 Acid phosphatase activity in roots of pigeonpea genotypes under $+\mathrm{P}$ and $-\mathrm{P}$ condition

\section{$\square \mathrm{AL} 1817 \square \mathrm{AL201} \square \mathrm{AL1758}$ 口H005 $\square \mathrm{ICPL93081} \square \mathrm{ICPL88039}$}

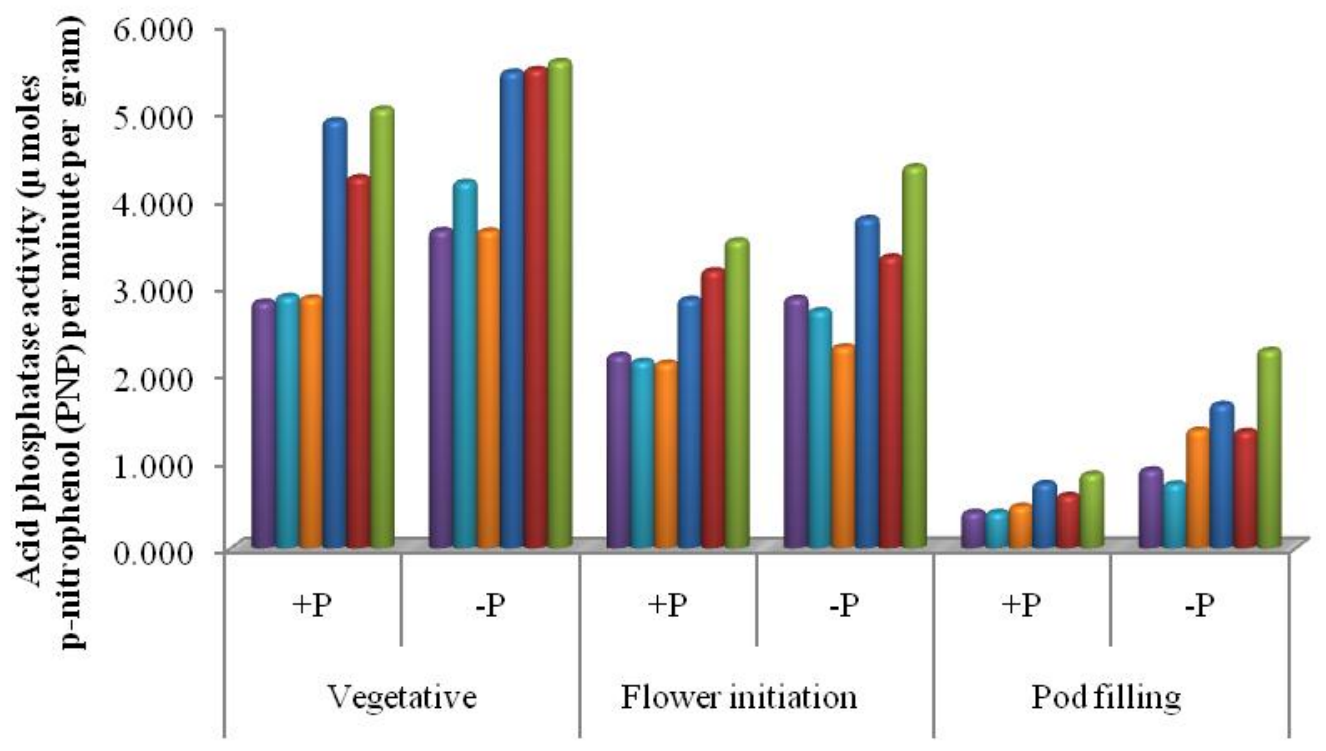


Fig.5 Profile of APase isoforms from roots of pigeonpea genotypes at a) vegetative stage b) flower initiation and c) pod filling stage under $-\mathrm{P}$ and $+\mathrm{P}$
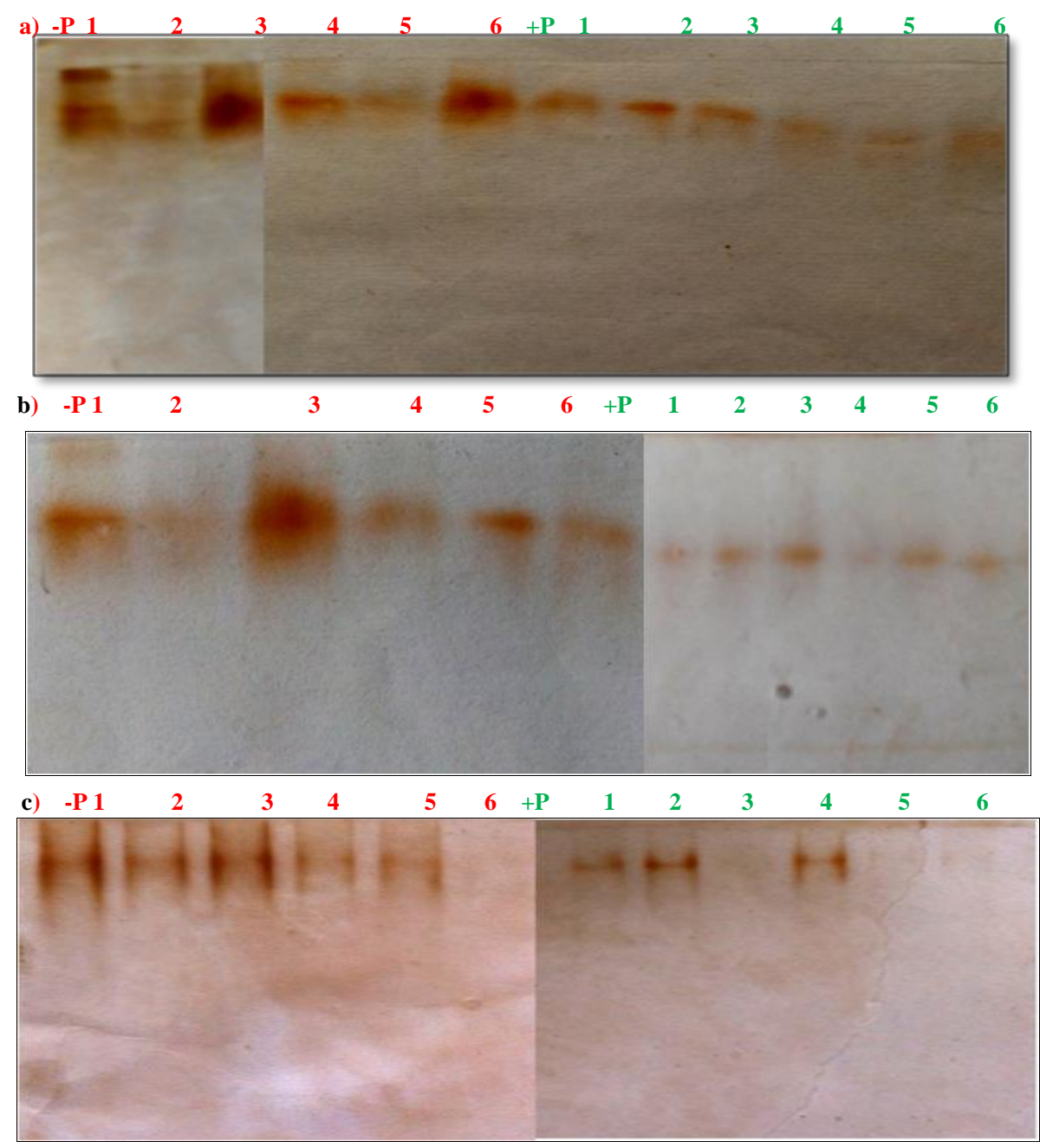

(1-ICPL88039, 2-ICPL93081, 3-H005, 4- AL201, 5- 1758, 6-1817)

Fig.6 Phosphorus content in leaf and root of pigeonpea genotypes under $+\mathrm{P}$ and $-\mathrm{P}$ conditions

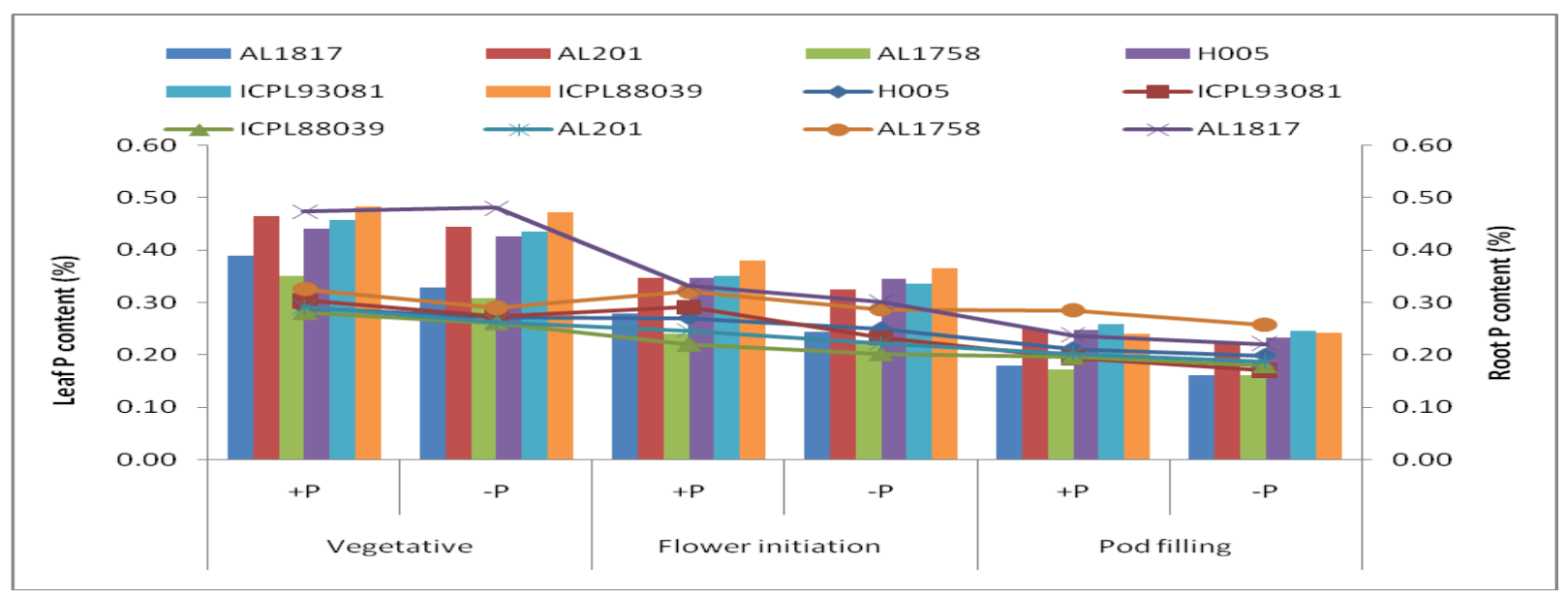


Fig.7 Anatomical structure of lateral roots of a) ICPL88039, b) AL1758, c) transverse sections of root of ICPL88039 and d) AL1758. ( $a$ and b - 400 $\mu \mathrm{m}, \mathrm{c}$ and d- $500 \mu \mathrm{m}$ )

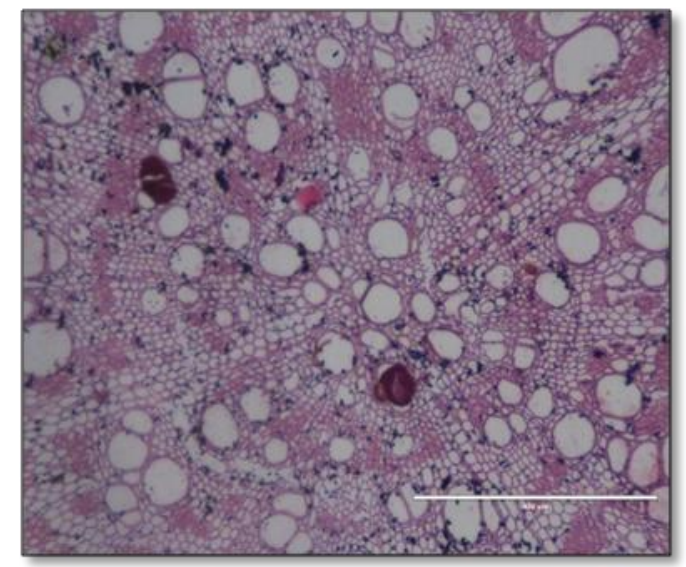

a)

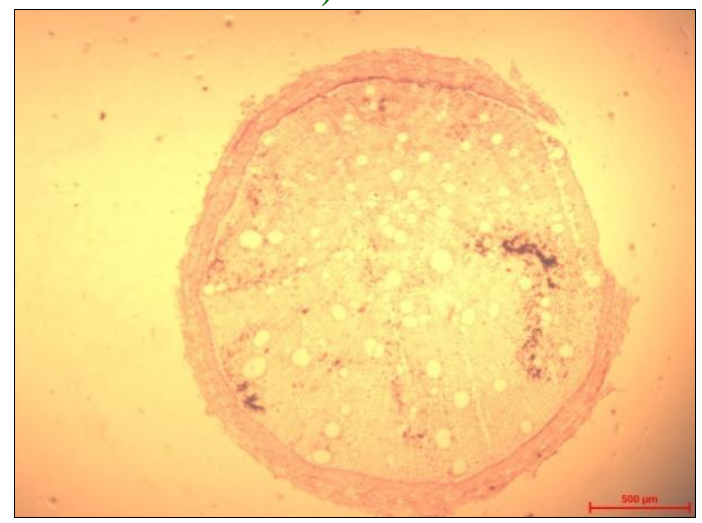

c)

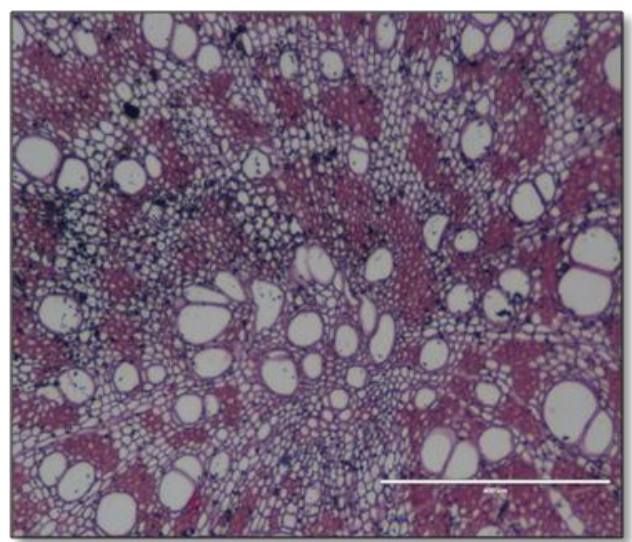

b)

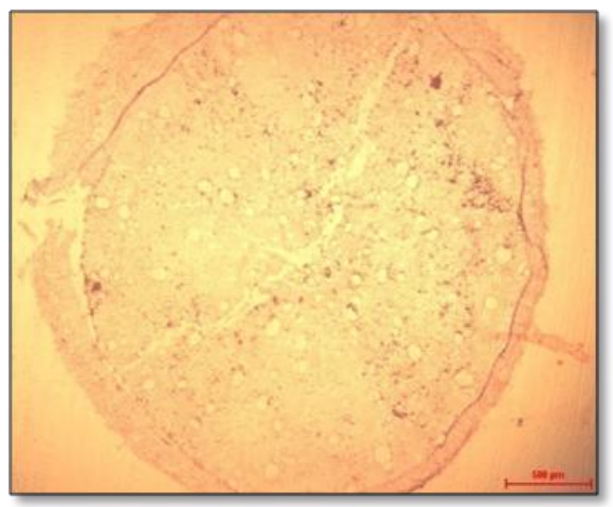

d)

Fig.8 Yield (kg/ha) of pigeonpea genotypes

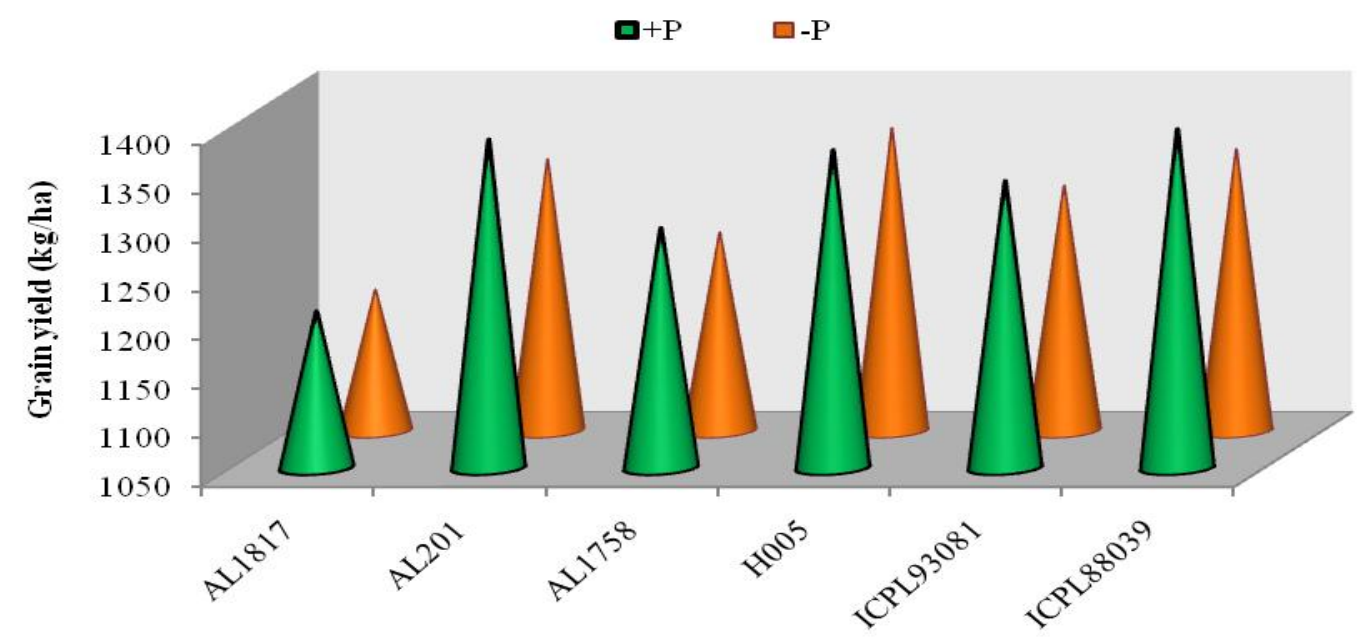


These results indicate that no added $\mathrm{P}$ led to increase in some of the protein band intensities and even formation of new proteins in some genotypes as compared $\mathrm{P}$ recommended dose condition. The change in band intensity due to no added $\mathrm{P}$ treatment apparently is indicative of enhancement of gene expression in the genotypes. Two major APase isoforms were detected in lupine root; one isoform was induced in proteoid roots under Pi-deficient conditions (Gilbert et al., 1999). The root-associated APases pool increased in Arabidopsis when $\mathrm{Pi}$ was limiting; five isoforms was detected in which one isoform increased as response to low $\mathrm{Pi}$ (Tomscha et al., 2004).

\section{Phosphorus content (leaf and root)}

The partitioning of $\mathrm{P}$ from root to the leaves increased at $\mathrm{P}$ not added condition in $\mathrm{P}$ use efficient genotypes. Genotypes ICPL88039, ICPL93081 and H005 accumulated more P in leaves (Fig. 6). More P accumulation in roots showed less $\mathrm{P}$ utilization and low $\mathrm{P}$ concentration of root showed high $\mathrm{P}$ utilization in shoot parts. High $\mathrm{P}$ uptake genotypes retained more $\mathrm{P}$ in leaves in $\mathrm{P}$ deficient and sufficient condition, revealed better mobilization of $\mathrm{P}$ in leaves from roots (Krishnappa et al., 2011).

\section{Lateral root anatomical studies}

Lateral roots of ICPL88039 and AL1758 were sectioned and observed for anatomical changes at 60 days after sowing. Diameter of lateral root of ICPL88039 $(0.742 \mathrm{~mm})$ and AL1758 (0.482 mm) were measured (Table 4, Fig. 7).

Genotype ICPL88039 had the maximum number of small xylem vessels (50) and AL1758 had the maximum number of large metaxylem vessels (19). Ramamoorthy et al., (2013) studied six legume crops which were grown under drought condition. Among six legmes, root segments of pigeonpea demonstrated 26, 18 small xylem vessels and large metaxylem vessels with $9.6 \mu \mathrm{m}$ average size of xylem vessels.

\section{Yield and attributes}

Seed yield was found maximum in ICPL88039 followed by AL201 and H005 while minimum in AL1817 under P recommend dose condition (Fig. 8). The reduction in yield of $\mathrm{P}$ use non efficient genotypes was more pronounced.

In conclusion, genotypic variation to acquire and utilize $\mathrm{P}$ from soil was observed in this study under both $\mathrm{P}$ treatments. Overall, it is concluded that genotype performed better in terms of $\mathrm{P}$ content in plant parts, APase activity, photosynthetic rate and biomass accumulation rated as $\mathrm{P}$ use efficient under no added $\mathrm{P}$ condition.

Phosphorus use efficient genotype showed higher relative root growth because of the additional $\mathrm{P}$ taken up by roots, allow further biomass accumulation which leads to more production. Phosphorus use efficient pigeonpea genotypes developed various adaptive strategies such as improved root morphology, biochemical (root APase acitivity, $\mathrm{P}$ content) and physiological characteristics (photosynthetic rate) to enhance the $\mathrm{P}$ acquisition and utilization efficiency under $\mathrm{P}$ fertilizer not added in soil condition.

\section{Acknowledgment}

The first author would like to thank Department of Science \& Technology, New Delhi, India for their financial support to conduct this study through Women Scientist Scheme (A) programme (C/458/IFD/201516). 


\section{References}

Abelson, P. H. 1999. A potential phosphate crisis. Sci., 283: 2015.

Ciereszko, I. Z., Ebrowska, E., and Ruminowicz, M. 2011. Acid phosphatases and growth of barley (Hordeum vulgare L.) cultivars under diverse phosphorus nutrition. Acta. Physiol. Plant., 33: 2355-68

Clemens, C. M., Gerard, C., and Olga, E. S. 2016. Improving phosphorus use efficiency in agriculture: opportunities for breeding. Euphy., 207: 1-22.

Cordel,1 D., Drranget, J. O., and White, S. 2009. The story of phosphorus: global food security and food for thought. Glob. Environ. Change. 19: 292-305.

De Groot, C. C., Marcelis, L. F. M., Van, Dew., Boogaard, R., and Lambers, H. 2001. Growth and dry-mass partitioning in tomato as affected by phosphorus nutrition and light. Plant Cell Environ., 24: 1309-17.

Gutschick, V. P., and Kay, L. E. 1995. Nutrient-limited growth rates: quantitative benefits of stress responses and some aspects of regulation. $J$ Exp Bot., 46: 995-1009.

Hodge, A. 2004. The plastic plant: root responses to heterogeneous supplies of nutrients. New Phytol 162: 9-14.

http://www.indiastat.com/

Jackson, M. L., (1973) Soil Chemical Analysis. pp 485Published by Printice Hall, New Delhi.

Jain, A., Poling, M. D., Karthikeyan, A. S., Blakeslee, J. J., Peer, W.A., Titapiwatanakun, B., Murphy, A. S., and Raghothama, K. G. 2007. Differential effects of sucrose and auxin on localized phosphate deficiencyinduced modulation of different traits of root system architecture in Arabidopsis. Plant Physiol., 144: 232-47.

Karthikeyan, A. S., Varadarajan, D. K., Jain, A., Held, M. A., Carpita, N. C., and
Raghothama, K. G. 2007. Phosphate starvation responses are mediated by sugar signaling in Arabidopsis. Planta 225: 907-18.

Kouas, S., Debez, A., Slatni, A., Labidi, N., Drevon, J. J., and Abdelly, C. 2009. Root Proliferation, Proton Efflux, and Acid Phosphatase Activity in Common Bean (Phaseolus vulgaris) Under Phosphorus Shortage.J. Plant. Biol. 52:395-402

Krishnappa, R., Umesh, H. R., and Hussain, A. I. S., 2011. Variations in phosphorus uptake and its utilization in pigeonpea genotypes grown under phosphorus deficiency. J. Food. Legumes. 24: 96100.

Krishnappa, R., and Hussain, A. I. S. 2014. Phosphorus acquisition from deficient soil: involvement of organic acids acid phosphatase in pigeonpea. Ind. J. Plant. Physiol. 19(3): 197-204.

Lambers, H. Y., Shane, M. W., Cramer, M. D., Pearse, S. J., and Veneklaas, E. J. 2006. Root structure and functioning for efficient acquisition of phosphorus: matching morphological and physiological traits. Ann. Bot. 98: 693713.

Manschadi, A. M., Manske, G. G. B., and Vlek, P. L. G. 2013. Root Architecture and Resource Acquisition - Wheat as a Model Plant. In: Eschel, A., Beeckman, T. (Eds.), Plant Roots: The Hidden Half., fourth ed. CRC Press, Taylor \& Francis Group, USA, pp. 22.1-22.18.

Marschner, H. 1998. Role of root growth, arbuscular mycorrhiza, and root exudates for the efficiency in nutrient acquisition. Field. Crops. Res., 56: 20307.

Plaxton, W. C. 2004. Plant responses to stress: biochemical adaptations to phosphate deficiency. InRM Goodman, ed, Encyclopedia of Plant and Crop Science. Marcel Dekker, New York, pp 
976-80.

Ramamoorthy, P., Mainassara, Z., Nalini, M., Rajaram, P., Lakshmanan, K., Cholenahalli, L., and Laxmipathi, G., 2013. Root anatomical traits and their possible contribution to drought tolerance in grain legumes. Plant Production Science 16 (1) 1-8

Rao, I. M., Kerridge, P. C., and Macedo, M. 1996. Nutritional requirements of Brachiaria and adaptation to acid soils.In Miles JW, Maass BL, DoValle CB (eds) Brachiaria: biology, agronomy and improvement. CIAT, Colombia pp. 53-71.

Rengel, Z., and Marschner, P. 2005. Nutrient availability and management in the rhizosphere: exploiting genotypic differences. New Phytol 168: 305- 12.

Rubya, Shabnam., and Md, Toufiq. Iqbal. 2016. Phosphorus use efficiency by wheat plants that grown in an acidic soil. Braz J of Sci and Techno DOI: 10.1186/s40552-016-0030-7

Sass, J. E. 1958. Botanical microtechnique. Lowa state College Press, Ames

Schachtman, D. P., Reid, R. S., and Ayhing, S. M. 1998. Phosphorus uptake by plants from soil to cell. Plant Physiol 166: 447-53.

Singh, V. K., Dwivedi, B. S., Shukla, A. K., Chauhan, Y. S., and Yadav, R. L. 2005 Diversification of rice with pigeonpea in a rice-wheat cropping system on a Typic Ustochrept: effect on soil fertility, yield and nutrient use efficiency. Field Crops Res 92: 85-105.

Veneklaas, E. J., Lambers, H., Bragg, J., Finnegan, P. M., Lovelock, C. E., Plaxton, W. C., Price, C. A., Scheible, W. R., Shane, M. W., White, P. J., and Raven, J. A. 2012. Opportunities for improving phosphorus-use efficiency in crop plants. New Phytol 195: 306-20.

Wang, X., Shen, J. and Liao, H. 2010. Acquisition or utilization, which is more critical for enhancing phosphorus efficiency in modern crops? $\mathrm{Pl}$ Sci., 179: 302-06.

Wissuwa, M., Mazzola, M. and Picard, C. 2009. Novel approaches in plant breeding for rhizosphere-related traits. Plant Soil 321: 409-30.

Wissuwa, M., Wegner, J., Ae, N. and Yano, M. 2002. Substitution mapping of Pup 1: a major QTL increasing phosphorus uptake of rice from a phosphate deficient soil. Theo Appl Genet., 105: 890-97.

Yan, X., Liao, H., Beebe, S. E., Blair, M. W. and Lynch, J. P. 2004. QTL mapping of root hair and acid exudation traits and their relationship to phosphorus uptake in common bean. Plant Soil 265: 17-29.

\section{How to cite this article:}

Sukhpreet Kaur Sidhu, Jagmeet Kaur and Satvir Kaur Grewal. 2017. Genotypic Variation for Phosphorus Efficiency of Pigeonpea Genotypes under Varied Phosphorus Levels. Int.J.Curr.Microbiol.App.Sci. 6(11): 3633-3647. doi: https://doi.org/10.20546/ijcmas.2017.611.425 